DOI 10.15393/j9.art.2015.2925

УДК 821.161.1.09“18“-3

Вячеслав Михайлович Головко

Северо-Кавказский федеральный университет (Ставрополь, Российская Федерация) vmgolovko@mail.ru

\title{
БИБЯЕЙСКИЙ КОНТЕКСТ МОТИВА САМООТВЕРЖЕНИЯ В СЮЖЕТЕ «СТРАННОЙ ИСТОРИИ» И. С. ТУРГЕНЕВА
}

Аннотация. В статье рассматривается функциональная роль библейских реминисценций в повести-студии И.С. Тургенева «Странная история» (1870). Претекстовая функция Библии и экзегеза отдельных библейских положений, изречений и максим развертываются в процессе художественного раскрытия нравственного выбора Софи и воплощения экзистенциального мотива. В этике самоотвержения главная героиня повести опирается на ветхозаветные догматы и евангельские благовествования и одновременно утверждает собственное понимание необходимости «жертвования собою» во имя осуществления нравственного идеала. Нравственные воззрения Софи хотя и формировались под влиянием религиозной этики, однако не сводятся к ней. Вера в Христа у героини дополняется осознанием долга перед людьми. Библейская этика самоотвержения строится на антиномии эгоцентризма и отказа от своего «я». Личное последовательно приносится в жертву общему. Это роднит Софи с самоотверженными девушками, участницами народнического движения, и характеризует мироощущение нового человека, человека переходного времени в «национальной истории».

Ключевые слова: И. С. Тургенев, мотив, самоотвержение, вера, библейские реминисценции, контекст, претекст, субъект речи, субъект сознания, нравственно-эстетическая позиция автора

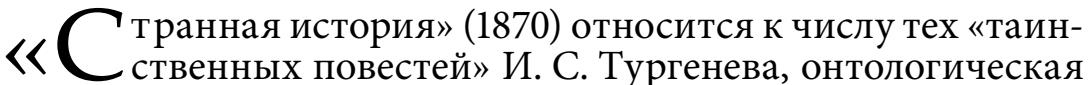
поэтика которых до сих пор остается открытой, привлекательной для историков литературы проблемой. Это произведение всегда трактовалось по-разному, в том числе и с точки зрения выраженности в нем традиций христианской культуры. Например, известный беллетрист XIX века 
М. В. Авдеев этику отречения, в системе которой изображается главная героиня повести Софи, связывал исключительно с комплексом религиозного фанатизма. «В основании всякого фанатизма лежит сила, но сила глупая, - писал он автору “Странной истории” сразу после появления произведения в печати, - и Софи во мне, кроме презрительного сожаления, никакого участия не шевельнула... Ваша Софи устарела» ${ }^{1}$ И. С. Тургенев не согласился с утверждением своего корреспондента о «несовременности» такого типа и таких форм проявления самоотвержения (П., VIII, 171)2 были им актуализированы в процессе художественного изображения нравственного, духовного подвижничества, «факела смирения» его главной героини.

По-иному о характере религиозности Софи писал И. Ф. Анненский. В главе «Белый экстаз» «Второй книги отражений» он выразил сомнение по поводу того, что в повести И. С. Тургенева осуществляется своего рода нравственно-эстетическая апробация одного из центральных понятий в христианстве - любви, которая, по св. Павлу, дана человеку Духом Святым (Рим. 5:5) наряду с верой и надеждой и, согласно Евангелию от Луки, является непременным условием для обретения права на вечную жизнь (Лк. 10:25-28). «И только нетерпеливая мечта о счастье многих, если можно, так даже всех, и придавала смысл жизни и подвигу “тех девушек”, - писал автор "Книг отражений”. - Но причем же счастье, если ищешь понять спутницу юродивого? Я скажу даже более, - продолжал И. Ф. Анненский, - причем в ее (Софи. - В. Г.) испытании самая любовь к ближнему, все равно в форме ли мистической, какою выстрадали ее христиане, назвав любовью к Богу, или в форме метафизической, какою признают ее социалисты, уча нас любить человечество. Бедной Софи нечем было любить Бога. Она жила одним изумлением, одной белой радостью небытия, о котором людям говорило только ее молчание» (курсив И. Ф. Анненского. - В. Г.) [1, 145].

То, что интуитивно почувствовал И. Ф. Анненский, подтверждается анализом функциональной роли библейских 
реминисценций в идейно-эстетической структуре произведения И. С. Тургенева, то есть текстологическим комментарием, позволяющим рассматривать Библию в качестве одного из источников текста этой повести. Но во всем ли прав автор «Книг отражений»? На многие спорные вопросы изучения «Странной истории» можно ответить только в процессе рассмотрения библейского контекста, в котором осуществляется художественное раскрытие этики самоотвержения как мировоззренческой основы духовных исканий и философии поступка главной героини повести. Претекст - в данном случае Ветхий и Новый Завет - в творческом процессе писателя играет немаловажную роль: в семантическом плане интертекстуальность раскрывается как способность тургеневского текста формировать собственный смысл посредством ссылки на библейские тексты.

«Странная история», как и многие другие художественные произведения писателя, генетически связана с концепцией его статьи-речи «Гамлет и Дон-Кихот» (1860). «Все люди живут - сознательно или бессознательно - в силу своего принципа, своего идеала, то есть в силу того, что они почитают правдой, красотою, добром», - писал И. С. Тургенев в этой статье (C., VIII, 172). Таким идеалом для героев донкихотского склада является самоотвержение, самопожертвование. Писатель с конкретно-исторических позиций рассматривал их стоицизм как форму «сохранения человеческого достоинства» (С., VIII, 191). К числу таких самоотверженных героев, стремящихся к высоким внеличным целям, относится и Софи Б. из «Странной истории». В религиозно-этической форме ее самоотвержения отражались тенденции времени начавшегося демократического движения в стране (время действия повести - 1850-е годы), а это движение способствовало росту социального и нравственного самосознания личности.

Данные процессы специфично преломились в духовных исканиях тургеневской героини [6, 99-108]. Свою «правду», которая коренится в вероучительных истинах Ветхого и Нового Завета и в то же время к ним не сводится, Софи 
противопоставляет собственническим и эгоистическим интересам провинциальной дворянской и мещанской среды.

Своеобразной идейной кульминацией произведения является диалог Софи и рассказчика, непосредственно предшествующий изображению «странной истории», то есть главного, основного события в жизни героини, оставившей дом богатой дворянской семьи и ставшей прислужницей юродивого. Этот диалог развивается при очевидном несоответствии речевых потоков, что способствует усилению его конфликтности.

Высказывания Софи показывают, что она, с одной стороны, в утверждении этики самоотречения опирается на ветхозаветные догматы и евангельские благовествования, а с другой, - что отходит от них в защите своего понимания идеала самопожертвования. Это важно для трактовки произведения и, прежде всего, сути нравственного подвига героини в соответствии с авторским замыслом. Такой характер интерпретации христианских идей в художественном мире произведения Тургенева необходимо учитывать и в тех случаях, когда некоторые исследователи пытаются доказать, что писатель “"объективно" воспринимает христианскую идею и образ Христа, о чем свидетельствует близость его боговидения народной традиции и православному канону» [2], или обосновать идею «личного освобождения человека» $[4,360]$, заложенную в христианской философии. Образом Софи писатель иллюстрировал и подтверждал свое высказывание о том, что «идеал дается только сильным гражданским бытом, искусством (или наукой) и религией», а «религия не всякому дается» (П., I, 366). Разработкой этого образа он показывал, что «истинно верующие люди вызывали у него не только уважение, но даже благоговение» [11, 161].

Категория самоотречения является одной из доминантных в этическом комплексе Библии. В разных аспектах это понятие раскрывается как в Ветхом, так и в Новом Завете. «Незыблемые и неискоренимые убеждения» (С., X, 175) Софи в том, что себя надо принести в жертву другим, «искоренить дотла... гордыню», вполне соответствуют духу многих 
библейских нравоучений. Они проявляются непосредственно (то есть в форме открытых и скрытых реминисценций) и ощущаются в общей атмосфере произведения. Нравственные позиции тургеневской героини соотносятся с одной из важных альтруистических идей Библии: «Никто не ищи своего, но каждый пользы другого» (курсив первоисточника. B. Г.) (1 Кор. 10:24). К Священному Писанию она апеллирует всякий раз, когда необходимо доказать истинность того, в чем искренне убеждена. Так, обосновывая свою веру в возможность чудесного, Софи прямо ссылается на Евангелие от Матфея (Мф. 17:20): «Да и как возможно не допускать их (чудес. - В. Г.)? - говорит она. - Разве не сказано в Евангелии, что у кого на одно горчишное семя веры, тот может горы поднимать с места? Нужно только веру иметь, - чудеса будут» (С., X, 175). «Вера» - это один из постулатов этики самоотвержения героини.

Библейский контекст развития темы самоотвержения воссоздается аллюзиями, параллелями, ассоциациями, отсылками, интертекстуальными формами, нередко выполняющими функции сюжетных мотивировок и появляющимися при изображении героев в разных сюжетных ситуациях. Так, «удивительные и таинственные... действия» «первого постника и молельщика» Василия, способного «по духу» вызывать души умерших людей, не только другим персонажам, но и Софи представляются выражением «божественности», «милости великой», данной ему «свыше»: она усматривает «богоугодность» в таком проявлении чудесного (С., X, $174,167,175)$, чем и вызвана ее апелляция к Евангелию от Матфея.

Сюжетно мотивированным является то, что в роли «наставника» Софи оказывается «в божественности очень сильный» Василий, способный «дела совершать чудесные» «показывать мертвых» (С., X, 165, 164). Как отмечал В. Н. Топоров, «Тургенев верил в реальность сверхчувственного мира и, более того, в минуты мистического прорыва она открывалась ему именно как реальность, бесспорная и несомненная по крайней мере в ее переживании. <...> Есть основания говорить о “мистическом" зрении Тургенева, о его 
“двойном” видении, позволяющем проникать ему в мир “призраков”» [12, 47-48]. Но если эта мистика самого писателя «была, по слову Зайцева, не православна» $[12,47]$, то для его героев она была проявлением именно «божественности».

Существенно, что в сознании рассказчика, узнавшего в случайно встретившихся ему на постоялом дворе юродивом, «божьем человеке», и в его спутнице, «тщедушной женщине», Василия и Софи, невольно возникает параллель с евангельскими образами: «Я снова глянул сквозь щель: женщина... все еще возилась с больной ногой юродивого. “Магдалина!” - подумал я» (С., Х, 179, 180-181).

Православная традиция связана с почитанием Марии Магдалины, преданной последовательницы Христа, служившей ему (Мк. 15:40-41; Лк. 8:3), исключительно как святой равноапостольной мироносицы. Данный евангельский контекст, создаваемый трактовкой образа Магдалины не католической, а именно православной церкви, чрезвычайно существенен для понимания содержательной сути основной коллизии тургеневской повести-студии. Не случайно выражением на лице «неподвижной задумчивости, тайного, постоянного изумления» Софи, эта «искренняя душа», «существо с особенным... неясным отпечатком», рождающее в сознании окружающих образ «молодой, серьезной, настороженной жизни», «напоминала... дорафаэлевских мадонн...» (С., Х, 177, 162). Художники раннего итальянского Возрождения Пьеро делла Франческо (1415-1492), Джованни Беллини (1430-1516), Козимо Тура (1430-1495), Карло Кривелли (1435-1495) и др. сохраняли связи с византийской культурой, с традициями средневековой иконографической живописи. Картина «Мадонна с благословляющим младенцем и двумя ангелами» («Мадонна Сенигалья») Пьеро делла Франческо, художника-реформатора эпохи Кватроченто, созданная в 1491 году, строгостью изображения лиц и отсутствием эмоциональных связей между персонажами напоминает, например, христианские мозаики или византийские иконы. Или, скажем, «Мадонна с младенцем» («Мадонна с красными херувимами») Джованни Беллини (ок. 1490) дает представление о традиционной для этого художника манере 
изображения: на всех его картинах мадонны - «простые, серьезные, не печальные и не улыбающиеся, но всегда погруженные в ровную задумчивость. Это созерцательные и тихие души, в них есть полнота какого-то равновесия» ${ }^{3}$. Описание внешнего и психологического облика Софи в «Странной истории» («лицо... с неподвижными чертами», «серьезность», «отсутствие улыбки», «глаза, постоянно и прямо устремленные в глаза собеседника, которые... будто видят что-то другое, чем-то другим озабочены», строгость внутренней «чистоты», «искренность») действительно, созвучно изобразительным трактовкам образов Богоматери в произведениях художников Раннего Возрождения. Рассказчик не раз подчеркивает «странность», «загадочность» Софи, то, что она была «не от земли сея» (С., Х, 162, 174). Но в «ровности», «равновесии» тургеневской героини скрывалась невероятная твердость характера, «догматическая» убежденность в «обязанности всякого» «делать то, что ему кажется правдой» (С., X, 176).

Возражая рассказчику, противопоставляющему религиозную идею «бессмертия души» заурядности реального человека («Вы полагаете, что, например, подле этого гарнизонного майора, с красным носом, может в эту минуту витать бессмертная душа?»), она говорит: «Для чистого нет ничего нечистого!» (С., X, 176). Полемическая направленность слов героини соответствует смыслу и сути одного из евангельских изречений святого апостола Павла: «Я знаю и уверен в Господе Иисусе, что нет ничего в себе самом нечистого; только почитающему что-либо нечистым, тому нечисто» (Рим. 14:14). В конце произведения автор вернется к этой мысли, чтобы подчеркнуть, что Софи, превратившаяся в Акулину, в «женщину в шушуне», во имя веры шла своим путем и «осталась чистой», так как для нее «не было ничего нечистого» в служении «полусумасшедшему бродяге» (C., X, 181, 185, 184).

В то же время вера героини «Странной истории», связанная с обоснованием экзистенциального комплекса самоотвержения, с этическим императивом самоотдачи во имя 
других, во всем своем значении не сводится только к проблемам религиозного мировоззрения. Софи осознает себя как экзистенцию не в контексте обыденного, а в ситуации свободного выбора в сторону самопожертвования, «самоуничижения», «выбора самой себя», формирования себя нравственно ответственными поступками и действиями. Рассказчика, с точки зрения которого ведется повествование, поражает, что Софи видит лишь один путь осуществления веры - «самоотвержение... уничижение!» (С., X, 175). Однако его позиция не совпадает с авторской, которая объективируется системной множественностью точек зрения автора на текст. Анализ библейских огласовок основной темы конфликтного диалога ведет к адекватному раскрытию замысла писателя. В этом диалоге сталкиваются две концепции веры: одна - традиционная, восходящая к Библии, традиционная настолько, что рассказчик позволяет себе говорить о ней даже с явной иронией, другая - противоречащая ей (точка зрения Софи).

В контексте библейских реминисценций высвечивается не столько религиозный фанатизм Софи Б. или «патология народной религиозной жизни», как утверждают некоторые исследователи [7], [9], [10], [8, 310], сколько нравственно-гуманистические основы мировоззрения героини Тургенева. В эпицентре диалога героев не случайно оказывается именно проблема верь.

Вот квинтэссенция диалога героев, тему которого подает Софи: «Вера не перевелась в наше время; а начало веры...»«Начало премудрости страх Божий», - перебил я (рассказчик. - В. Г.). «Начало веры, - продолжала Софи, нисколько не смутившись, - самоотвержение <...> уничижение» (С., X, 175).

Слова рассказчика - это раскавыченная цитата из «Книги Притчей Соломоновых» и «Книги Иова»: «Начало мудрости - страх Господень» (Притч. 1:7; 9:10), «страх Господень есть истинная премудрость, и удаление от зла - разум» (Иов. 28:28). По свидетельству богословов, библейскому понятию Страх Господень «соответствует на современном 
языке благоговение перед Богом <..> Такое отношение к святыне есть начало <...> и венец религиозной мудрости; при наличии ее отношения человека с Богом развиваются таким образом, что страх и любовь, повиновение и доверие сочетаются» ${ }^{4}$.

Религиозная интерпретация «мудрости» и «веры» содержится, например, в «Опытах» М. Монтеня («Апология Раймунда Сабундского»), ссылавшегося в этом случае на те же идеи Евангелия от Матфея, что и Софи, говорившая о силе веры [ср.: Мф. 17:20 и С., Х, 175]: «Если бы в нас была хоть капля веры, то мы, как говорится в Священном Писании, способны были бы двигать горами; наши действия, будучи направляемы и руководимы божеством, не были бы просто человеческими: в них было бы нечто чудесное, как и в нашей вере» ${ }^{5}$. И «человеческий разум», удаляющий от зла, в соответствии с «Книгой Иова», Монтень «считал единственным нашим руководителем» ${ }^{6}$. «Ппыты» Монтеня еще раз подтверждают, что в слова рассказчика о «страхе Господнем» писатель вкладывал мысль о «благоговении перед Богом». Уместно вспомнить, что Тургенев хорошо знал и очень высоко ценил творчество Монтеня, неоднократно намеревался перевести «Опыты» на русский язык (П., XII, кн. 1, 101; XIII, кн. 1, 76). В библиотеке писателя, хранящейся ныне в Орловском государственном литературном музее И. С. Тургенева, имеются некоторые части женевского издания «Опытов» 1779 года.

Ответ Софи («Начало веры <..> самоотвержение <...> уничижение!») - это, казалось бы, смелый вызов освященному ореолом святости библейскому изречению, но, по сути, он остается в компетенции библейской этики, которой отрицается «гордыня» и эгоцентризм. Лишь на первый взгляд кажется, что рассказчик и Софи говорят о разном: один о «премудрости», другая - о «вере». В свете библейских нравоучений становится очевидной взаимосвязь этих категорий. Другое дело, что вера понимается ими по-разному. Точнее, у Софи она есть, а у ее оппонента она просто отсутствует, потому он с ироническим оттенком и цитирует каноническое, библейское изречение. 
Однако не случайно и то, что слова героини о самоотвержении как начале веры, которое она вольно или невольно противопоставляет идее благоговения перед Богом, не имеют прямых аналогов в поучениях Ветхого и Нового Завета. Тургенев подчеркнул тем самым, что нравственные воззрения Софи хотя и формировались под влиянием религиозной этики, однако не сводятся к ней. «Вера» во имя Христа у героини дополняется верой во имя долга перед людьми. В результате происходит переакцентуация целевых основ «премудрости» во имя утверждения этики самоотвержения в ее общественно-нравственном содержании, которая тоже «удаляет от зла». Создается такая художественная ситуация, которая может быть определена словами из «Рассказа старшего садовника» А. П. Чехова: «Веровать в Бога нетрудно. В него веровали и инквизиторы, и Бирон, и Аракчеев. Нет, вы в человека уверуйте! Эта вера доступна только тем немногим, кто понимает и чувствует Христа» ${ }^{7}$.

Библейская этика самоотвержения строилась на антиномии эгоцентризма и отказа от своего «я»: «...я ни на что́ не взираю и не дорожу своею жизнью, только бы с радостью совершить поприще мое и служение, которое я принял от Господа Иисуса... И ныне, вот, я знаю, что уже не увидите лица моего все вы, между которыми ходил я...» (Деян. 20:24, 25) (курсив евангельского текста. - В. Г.). Но при этом: «...ненавидящий душу свою в мире сем сохранит ее в жизнь вечную» (Ин. 12:25). С одной стороны, Софи, осуществившая свое стремление к самопожертвованию, доказала, что «вера без дел мертва» (Иак. 2:20); с другой, - в повести-студии показано, что человек, находящийся в системе отречения, перестает, казалось бы, существовать как неповторимая индивидуальность. К этому стремилась Софи и достигла желаемого, «заставив топтать, попирать себя ногами» (С., X, 185).

Однако это больше внешние переклички с библейской этикой самоотвержения. Тургеневская героиня «искореняет дотла» свою «гордость», пытается «сломить» свою «волю» (С., X, 176), добивается самоуничижения, не «дорожит своей жизнью», менее всего имея в виду ту идею, которая с афористической точностью выражена в Евангелии от Матфея: 
«Ибо кто хочет душу (жизнь) свою сберечь, тот потеряет ее; а кто потеряет душу свою ради Меня (Христа. - В. Г.), тот обретет ее» (Мф. 16:25). Приверженности такому убеждению у Софи не обнаруживается, и не случайно об этом в произведении не сказано ни одного слова. Не удивительно, что героиня отказывается видеть в роли наставника и учителя своего духовника, ищет его в человеке реального действия: «Батюшка мой духовный говорит мне, что я должна делать; но мне нужен такой наставник, который сам бы мне на деле показал, как жертвуют собою!» (С., X, 176).

Самоотвержение Софи как позиция и поступок находится, с одной стороны, в притяжении смыслового поля кантовского категорического императива ${ }^{8}$, а с другой, - в парадигматическом отношении может рассматриваться как авторское предчувствие, предвосхищение антропологии и этики экзистенциализма XX века. Это вполне закономерно, поскольку мотив самоотвержения в «Странной истории» художественно интерпретирован именно как экзистенциальный. В ней «человек оказывается существом, которое постоянно ищет самого себя, которое в каждый момент своего существования испытывает и перепроверяет условия своего существования. В этой перепроверке, в этой критической установке по отношению к собственной жизни и состоит реальная ценность этой жизни» ${ }^{9}$. Данное базисное положение философии человека неокантианца Э. Кассирера может быть определяющей основой аксиологических критериев героини повести-студии И. С. Тургенева.

Вместе с тем мотив самоотвержения как свободного выбора, доминантный в художественной системе этого произведения, разворачивается в многосложный спектр значений при рассмотрении его в контексте онтологии современного экзистенциализма. Системообразующие в философии Н. А. Бердяева, Ж.-П. Сартра, М. Хайдеггера и других экзистенциалистов проблемы смысла жизни, индивидуальной свободы и ответственности входят в круг жизненных исканий тургеневской героини. Выбор Софи - это результат не рациональной интеллектуальной интенции, а форма самосозидания, творение себя, реализация «фундаментального 
проекта» - своего «я», которое осуществляется имманентно, так как героиня И. С. Тургенева в своем внутреннем мире не зависима от любого внешнего влияния, что, по Сартру, является выражением подлинной свободы постоянно развивающегося человеческого существа. Этот выбор человеком «самого себя» «есть “доонтологическое понимание” бытия, которое включено в каждый образ действия "человеческой реальности”, то есть в каждый из ее проектов» ${ }^{10}$. Свободный выбор Софи в соответствии с ее «верой» и воплощение в поступок ее представления о «правде», то есть нравственно ответственное действие как «проект самой себя», не создают в то же время сартровского экзистенциального конфликта «бытия-для-себя» и «бытия-для-другого». Более того, словами из сочинения Сартра «Бытие и ничто» можно сказать о том, что, с одной стороны, поступок Софи показывает, что «быть свободным - это значит быть-свободным-чтобыдействовать, а это есть свободное-бытие-в-мире» ${ }^{11}$; с другой же, что «всякое для-себя есть свободный выбор...», что «свобода есть выбор бытия Бога, и все <..> действия, все <..> проекты выражают и отражают его множеством способов»12.

Казалось бы, поступок Софи должен демонстрировать типично сартровский тезис: выбор - это всегда «вопреки», поскольку свободный выбор сопровождается преодолением многих препятствий. Но в данном случае «вопреки» - это не внутреннее сопротивление, а конфликт с теми окружающими героиню людьми, которые не могут понять смысла ее духовного подвига, в том числе и с ее родными, которым «удалось <...> отыскать заблудшую овцу и вернуть ее домой», где она «пожила недолго и умерла “молчальницей”» (С., X, 185). В принципе же в соотношениях «проект своего бытия-в-мире» ${ }^{13}$ и «бытие-для-другого» в коллизии произведения лишаются «первоначального смысла», отрефлексированного в экзистенциализме, - конфликтности.

«Конфликт есть первоначальный смысл бытия-для-другого, - писал Ж.-П. Сартр в третьей главе "Конкретные отношения с другим” части третьей “Для-другого” сочинения “Бытие и ничто”. - Если мы исходим из первичного 
открытия другого как взгляда, то должны признать, что испытываем наше непостижимое бытие-для-другого в форме обладания. Мною владеет другой» ${ }^{14}$. Поскольку «отношение к другому является совокупностью проектов» в системе фундаментального проекта, каковым является самосозидание личности, то «эти проекты ставят» человека «в непосредственную связь со свободой другого» ${ }^{15}$. Именно в этом смысле, подчеркивал философ, даже любовь является конфликтом ${ }^{16}$. «Любовь есть действие, то есть органическая совокупность проектов к моим собственным возможностям, писал Ж.-П.Сартр. - Но он является идеалом любви, ее мотивом и ее целью, ее собственной ценностью. Любовь как первичное отношение к другому является совокупностью проектов, которыми я намерен реализовать эту ценность» ${ }^{17}$. "Любовь к ближнему» становится «действием», то есть ценностной категорией этики героини, но в христианском ее понимании: если Сартром доказывалось, что «единство с другим не реализуемо» ${ }^{18}$, то самоотвержение Софи, в конечном счете, имеет целью именно «единство с Другим». Если для нее «любовь» и «является действием, то есть проектом самой себя» ${ }^{19}$, то «проектом» только ради Другого, «проектом» осуществления евангельских благовествований.

Именно поэтому самопожертвование тургеневской героини во имя Другого, ее самоуничижение не создает ситуацию конфликтности, напротив, рождает в ней чувство согласия с самой собою, с Другим, является действенным выражением «веры», подтверждением того, что «вера»- это «согласие бытия со своим объектом» ${ }^{20}$. В философии Сартра аргументировалось положение о том, что «самообман есть вера, и существенной проблемой самообмана является проблема веры ${ }^{21}$, в произведении же Тургенева показано, что именно истинность «веры» ведет Софи по пути служения тому, что она «почитала правдой» (С., Х, 184, 177).

Сопоставляя нравственное кредо Софи с религиозной этикой, писатель не только подчеркивал значимость и силу убеждений героини, но и раскрывал общечеловеческие основы ее действенного гуманизма. В то же время рассказчик 
не случайно «прения» с Софи называет «quasi богословскими» (C., X, 177): несмотря на религиозность, она чужда пиетета перед «страхом Господним». (Подобные несовпадения, возможно, и дали основание Н. Л. Бродскому утверждать, что Тургенев в «Странной истории» изображал мир и быт русских сектантов [3], а И. Ф. Анненскому в «Книгах отражений» - отказывать Софи в христианском понимании «любви к ближнему») [1]. Формы выполнения общественно-нравственного долга Софи не могли не вызывать сожаления у рассказчика г-на Х...: «Я не мог не сожалеть, что Софи пошла именно этим путем, но и отказать ей $<\ldots>$ в уважении я также не мог. <..> Я не понимал поступка Софи; но я не осуждал ее» (С., X, 185). В то же время автор высоко оценивает нравственный ригоризм героини. В «Странной истории» субъект речи со всей очевидностью не совпадает с субъектами сознания: формальный носитель речи здесь один (г-н Х...), а содержательных субъектов - несколько, что вообще характерно для нарративной системы реалистического стиля, когда под номенклатурой одного повествовательного «я» может быть несколько субъектов сознания.

В конце произведения дается оценка героини с позиций автора-повествователя (субъект сознания, не идентичный основному субъекту речи), который имеет в тексте свою содержательно-формальную сферу: «...у ней слова не рознились с делом» (выделено И. С. Тургеневым. - В. Г.) (С., Х, 185). Личное у Софи последовательно приносится в жертву общему. Это и роднит ее с самоотверженными девушками, участницами народнического движения, которые, по словам автора-повествователя, «так же пожертвовали всем тому, что они считали правдой, в чем они видели свое призвание» (выделено И. С. Тургеневым. - В. Г.) (С., Х, 185). Самоотречение Софи как родовое начало наполняется, таким образом, совершенно конкретным социально-нравственным смыслом, что, кстати, не было замечено И. Ф. Анненским.

Библейские претексты помогают прокомментировать некоторые «непрочитанные» места повести-студии И. С. Тургенева. Они выполняют смыслопорождающую функцию, 
способствуют воссозданию процесса рождения мироощущения нового человека, человека переходного времени, ставшего предметом художественного познания и анализа в этом произведении писателя. Концепция самоотвержения героини соотнесена в «Странной истории» с «требованиями национальной истории». Достоверности в передаче «духа времени» способствует и воссоздание исторически обусловленного восприятия идей Вечной книги.

\section{Примечания}

${ }^{1}$ Тургеневский сборник: Материалы к Полному собранию сочинений и писем И. С. Тургенева. М.; Л.: Наука, 1964. Т. 1. С. 430-431.

${ }^{2}$ Тургенев И. С. Полное собрание сочинений и писем: в 28 т. - М.: Изд-во АН СССР, 1960-1968. Далее ссылки на это издание приводятся в тексте статьи с указанием серии С. (Сочинения), П. (Письма), тома (римск.) и страниц (арабск.) в круглых скобках.

${ }^{3}$ Муратов П. П. Образы Италии: в 3 т. Берлин, 1924. Т. 1 [Электронный pecypc]. URL: http://az.lib.ru/m/muratow_p_p/text_0010.shtml (20.05.2015).

${ }^{4}$ Библия. - Брюссель: Изд-во «Жизнь с Богом», 1983. С. 1957.

${ }^{5}$ Монтень Мишель. Опыты: в 3 кн. М.: Голос, 1992. Кн. 2. С. 117.

${ }^{6}$ Там же. С. 531.

7 Чехов А. П. Полное собрание сочинений и писем: в 30 т. Сочинения. М.: Наука, 1977. Т. 8. С. 343.

${ }^{8}$ О связях произведений Тургенева с философией Канта см.: [5].

${ }^{9}$ Кассирер Э. Опыт о человеке: Введение в философию человеческой культуры // Проблема человека в западной философии. М.: Прогресс, 1988. C. 8.

${ }^{10}$ Сартр Ж.-П. Бытие и ничто: Опыт феноменологической онтологии. М.: Республика, 2000. 639 с. «Часть первая: Проблема ничто», глава I «Источник отрицания», раздел 3 «Диалектическая концепция ничто» [Электронный ресурc]. URL: http://www.psylib.org.ua/books/sartr03/ index.htm (22.05.2015).

${ }^{11}$ Там же. «Часть четвертая: Обладание, действие и бытие», глава 1 «Бытие и действие: свобода», раздел 2 «Свобода и фактичность: ситуация».

${ }^{12}$ Там же. «Часть четвертая: обладание, действие и бытие», глава 2 «Действие и обладание», раздел «Экзистенциальный психоанализ». 
${ }^{13}$ Там же. «Часть третья: Для-другого», глава III «Конкретные отношения с другим», раздел 1 «Первая установка по отношению к другому: любовь, язык, мазохизм».

${ }^{14}$ Там же.

15 Там же.

16 Там же.

${ }^{17}$ Там же.

${ }^{18}$ Там же.

${ }^{19}$ Там же.

${ }^{20}$ Там же. «Часть первая: Проблема ничто», глава II «Самообман», раздел 3 «"Вера" самообмана».

${ }^{21}$ Там же.

\section{Список литературы}

1. Анненский И. Ф. Книги отражений. - М.: Наука, 1979. - 680 с.

2. Белякова Е. Н. Христианская идея в художественном мире И. С. Тургенева и Ф. М. Достоевского: автореф. дис. ...канд. филол. наук. Кострома, 2000 [Электронный ресурс]. - URL: http://webcache. googleusercontent.com/search?q=cache:J4PjAgweWiwJ:www.dissercat. $\mathrm{com} /$ content/khristianskaya-ideya-v-khudozhestvennom-mire-i-sturgeneva-i-f-m-dostoevskogo $+\& c d=3 \& h l=r u \& c t=c l n k ~(15.05 .2015)$.

3. Бродский Н. Л. И. С. Тургенев и русские сектанты. - М.: Изд-во лит. кружка «Никитинские субботники», 1922. - 48 с.

4. Глазова-Корриган Е. Христианство как освобождение личности у И.С. Тургенева и Ф.М. Достоевского // Русская литература ХІХ века и христианство. - М.: Изд-во МГУ, 1997. - С. 356-360.

5. Головко В. М. Философский дискурс И. С. Тургенева как значимое целое: монография. - Ставрополь: Изд-во ФГАОУ ВПО «СевероКавказский федеральный университет», 2014. - 252 с.

6. Головко В. М. Художественно-философские искания позднего Тургенева (изображение человека). - Свердловск: Изд-во Уральск. гос. ун-та, 1989. - 168 с.

7. Лотман Л. М. Герой переходного времени // Лотман Л. М. Реализм русской литературы 60-х годов XIX века (Истоки и эстетическое своеобразие). - Л.: Наука, 1974 [Электронный ресурc]. — URL: http:// webcache.googleusercontent.com/search?q=cache:yI7732b6NMcJ:www. lotman.pushkinskijdom.ru/Default.aspx\%3Ftabid\%3D5854+\&cd=6\&hl $=\mathrm{ru} \& \mathrm{ct}=\operatorname{clnk}(15.05 .2015)$.

8. Масарик Т. Г. Россия и Европа: Эссе о духовных течениях в России / пер. с чешск. - СПб.: РХГИ, 2003. - Т. 3. - Кн. 3. - Ч. 2-3. - 576 с. 
[Электронный ресурc]. - URL: http://lib.philos.msu.ru/book/read/370 (17.05.2015).

9. Одесская М. М. Чехов и проблема идеала (Смена этико-эстетической парадигмы на рубеже XIX-XX веков): автореф. дис. ...канд. филол. наук. - М., 2011 [Электронный ресурc]. — URL: http://webcache. googleusercontent.com/search?q=cache:PzJXoaq-_A4J:plesetsk-info. ru/11-klass/chekhov-i-problema-ideala-smena-etikoesteticheskoiparadigmy-na-r $/+\& c d=271 \& h l=r u \& c t=c l n k(16.05 .2015)$.

10. Скуднякова Е. В. Фантастическое в поэтике «таинственных повестей» И. С. Тургенева: автореф. дис. ...канд. филол. наук. - Саранск, 2009 [Электронный ресурc]. - URL: http://webcache.googleusercontent. com/search?q=cache:qc2gnqET $79 \mathrm{UJ}:$ cheloveknauka.com/ fantasticheskoe-v-poetike-tainstvennyh-povestey-i-sturgeneva $+\& c d=10 \& h l=r u \& c t=\operatorname{clnk}(16.05 .2015)$.

11. Солодовник В.Н. Загадочная Лукерья. Проблемы восприятия западной критикой «русской религиозной духовности» (на материале рассказа И. С. Тургенева «Живые мощи») // Вестник Московского государственного областного университета. - Серия: Русская филология. -2009 . — № 2. - С. 160-170.

12. Топоров В.Н. Странный Тургенев (Четыре главы). - М.: Российск. гос. гуманит. ун-т, 1998. - 192 с. (Вып. 20) [Электронный pecypc]. - URL: http://webcache.googleusercontent.com/ search?q= cache:_c_g-BELVAwJ:ivgi.rsuh.ru/article.html\%3Fid\%3D2460938+\&cd= $1 \&$ hl $=$ ru\&ct=clnkht (27.04.2015).

Vyacheslav M. Golovko

North Caucasian Federal University

(Stavropol', Russian Federation) vmgolovko@mail.ru

\section{THE BIBLICAL CONTEXT OF SELF-REJECTION MOTIF IN THE PLOT OF IVAN TURGENEV'S “A STRANGE STORY”}

Abstract. The article studies the functional role of biblical reminiscence in Ivan S. Turgenev's short novel "A Strange Story" (1870). A pretextual function of the Bible and interpretations of certain biblical theses, sayings and maxims are revealed through the artistic analysis of moral choice of Sophie and the embodiment of the existential motif. In the ethics of selfexpression the main character of the short novel relies on the Old Testament dogmas and evangelical preaching as well as asserts her own understanding of the necessity of self-renunciation in the name of implementation of the moral ideal. Sophie's moral views despite being formed under the 
influence of religious ethics are not limited by the very ethics. Her faith in Christ is accompanied with the consciousness of her duty to people. The biblical ethics of self-dedication is based on antinomy of self-obsession and renunciation of one's own self. The personal is sacrificed for the sake of the public. This unites Sophie with the selfless girls, participants of the populist movement, and describes the world perception of a new person of the watershed times in the "national history".

Keywords: Turgenev, motif, the self-rejection renunciation, faith, biblical reminiscence, context, pretext, the subject of the speech, the subject of consciousness, moral and aesthetic stance of the author

\section{References}

1. Annenskiy I. F. Knigi otrazheniy [Books of reflections]. Moscow, Nauka Publ., 1979. 680 p.

2. Belyakova E. N. Khristianskaya ideya $v$ khudozhestvennom mire I. S. Turgeneva i F. M. Dostoevskogo. Avtoref. dis.... kand. filolog. nauk [A Christian idea in the artistic world of I. S. Tourgenev and F. M. Dostoevsky : PhD. philol. sci. diss. abstract]. Kostroma, 2000.151 p. Available at: http:// webcache.googleusercontent.com/search?q=cache:J4PjAgweWiwJ:www. dissercat.com/content/khristianskaya-ideya-v-khudozhestvennommire-i-s-turgeneva-i-f-m-dostoevskogo $+\& c d=3 \& \mathrm{hl}=\mathrm{ru} \& \mathrm{ct}=$ clnk (accessed 15 May 2015).

3. Brodskiy N. L. I. S. Turgenev i russkie sektanty [Turgenev and Russian sectarians]. Moscow, Nikitinskie subbotniki Literary circle Publ., 1922. $48 \mathrm{p}$.

4. Glazova-Korrigan E. Khristianstvo kak osvobozhdenie lichnosti u I. S. Turgeneva i F. M. Dostoevskogo [Christianity as a way of liberation of the individual]. Russkaya literatura XIX veka i khristianstvo [Russian Literature of the 19th century and Christianity]. Moscow, Moscow State University Publ., 1997, pp. 356-360.

5. Golovko V. M. Filosofskiy diskurs I. S. Turgeneva kak znachimoe tseloe: monografiya [I. S. Turgenev's philosophical discourse as a meaningful entity: the monograph]. Stavropol', FSAEI HPO North Caucasus Federal University Publ., 2014. 252 p.

6. Golovko V.M. Khudozhestvenno-filosofskie iskaniya pozdnego Turgeneva (izobrazhenie cheloveka) [Artistic and philosophical searches of the late Turgenev (depiction of a person)]. Sverdlovsk, Ural State University Publ., 1989. 168 p.

7. Lotman L. M. Geroy perekhodnogo vremeni [The Hero of the watershed times]. Lotman L.M. Realizm russkoy literatury 60-kh godov XIX veka (Istoki i esteticheskoe svoeobrazie) [Realism of Russian Literature 
of the 1860s (Origins and aesthetic peculiarities)]. Leningrad, Nauka Publ., 1974. Available at: http://webcache.googleusercontent.com/search?q= cache:yI7732b6NMcj:www.lotman.pushkinskijdom.ru/Default.aspx\%3F tabid\%3D5854+\&cd=6\&hl=ru\&ct=clnk (accessed 15 May 2015).

8. Masarik T. G. Rossiya i Evropa: Esse o dukhovnykh techeniyakh v Rossii [Russia and Europe: an essay about spiritual movements in Russial translated from Czech]. Saint-Petersburg, Publishing house of Russian Christian humanitarian Institute, 2003, vol. 3, book 3, part 2-3. 576 p. Available at: http://lib.philos.msu.ru/book/read/370 (accessed 17 May 2015).

9. Odesskaya M. M. Chekhov i problema ideala (Smena etiko-esteticheskoy paradigmy na rubezhe XIX-XX vekov). Avtoref. dis. ...kand. filolog. nauk [Chekhov and the problem of an ideal (The change of an ethic and aesthetic paradigm at the turn of the 19th-20th centuries): PhD. philol. sci. diss. abstract]. Moscow, 2011. Available at: http://webcache.googleusercontent.com/search?q=cache:PzJXoaq-_A4J:plesetsk-info.ru/11-klass/ chekhov-i-problema-ideala-smena-etikoesteticheskoi-paradigmy-na$\mathrm{r} /+\& \mathrm{~cd}=271 \& \mathrm{hl}=\mathrm{ru} \& \mathrm{ct}=\mathrm{clnk}$ (accessed 16 May 2015).

10. Skudnyakova E. V. Fantasticheskoe v poetike "tainstvennykh povestey» I. S. Turgeneva. Avtoref. dis... kand. filolog. nauk [The fantastic in I. S. Turgenev's poetics of "mystic stories": PhD. philol. sci. diss. abstract]. Saransk, 2009. Available at: http://webcache.googleusercontent.com/search?q=cac he:qc2gnqET79UJ:cheloveknauka.com/fantasticheskoe-v-poetiketainstvennyh-povestey-i-s-turgeneva $+\& c d=10 \& h l=r u \& c t=c l n k$ (accessed 16 May 2015).

11. Solodovnik V. N. Zagadochnaya Luker'ya. Problemy vospriyatiya zapadnoy kritikoy «russkoy religioznoy dukhovnosti» (na materiale rasskaza I. S. Turgeneva "Zhivye moshchi») [Mysterious Lukerya. The problems of perception of "Russian religious spirituality" by the European critics (based on the material of Ivan S. Turgenev's story "Walking corpse"]. Vestnik Moskovskogo gosudarstvennogo oblastnogo universiteta. - Seriya: Russkaya filologiya [Bulletin of Moscow State Regional University. - Series: Russian filology], 2009, no. 2, pp. 160-170.

12. Toporov V. N. Strannyy Turgenev (Chetyre glavy) [A strange Turgenev (Four chapters)]. Moscow, Russian State University for the Humanities Publ., 1998, issue 20.192 p. Availableat:http://webcache.googleusercontent. com/search?q=cache:_c_g-BELVAwJ:ivgi.rsuh.ru/article.html\%3Fid\%3D $2460938+\& c d=1 \& h l=r u \& c t=c l n k h t$ (accessed 27 April 2015).

Дата поступления в редакцию: 30.05.2015

(C) Головко В. М., 2015 